\title{
The Effect of Hypertriglyceridemia on Arterial Structure and Function Parameters in Patients with Metabolic Syndrome
}

Research

Keywords:

Posted Date: December 4th, 2020

DOI: https://doi.org/10.21203/rs.3.rs-108423/v2

License: (9) This work is licensed under a Creative Commons Attribution 4.0 International License.

Read Full License 


\section{Abstract}

The authors have requested that this preprint be withdrawn due to erroneous posting.

\section{Full Text}

The authors have withdrawn this preprint from Research Square. 